\title{
Efficient Causation and Continued Existence: Problem 9
}

In Section 9 of the Shukūk, al-Mas'ūdì targets a theory that serves as one of the cornerstones of Avicenna's cosmology and cosmogony. The commentary takes its cue initially from Ishärät II.4.10, which occurs in the context of Avicenna's proof for the existence of the Necessary of Existence through Itself, but it then turns to Ishārāt II.5.1-3, where the theory is set out in detail. The question at issue concerns, in the first place, both the process of efficient causation and the mode of existence that possible existents are possessed of, more particularly the problem of whether an effect depends on its agent with respect to its coming-to-be or its existence per se. This metaphysical problem is of central importance in both classical kaläm and Avicenna, who, as we shall see, frames his discussion in the Ishārāt first and foremost as a response to the theologians' conception of agency, and presents his own position as antithetical to theirs. The problem has broader implications, with the theologians' position being inextricably linked to their theory of creation ex nihilo, and Avicenna's to his theory that the world is pre-eternal.

\section{1}

\section{The Classical Kalām Background}

One of the key precepts of classical kalām is that an effect depends on (ihtāja $i \bar{a})$ its agent only for its coming-to-be (hudūth), but not for its continued existence $\left(b a q \bar{a}^{\prime}\right) .{ }^{1}$ This is what the theologians would class as a 'principle', or a 'primary doctrine' (așl), on which one or more 'secondary doctrines' (far') are premised. This primary doctrine finds its chief application in the classicalkalām cosmological proofs of the existence of God starting from creation ex nihilo; and it is in this context that the doctrine is normally substantiated. The Bahshamī Mu'tazila — the followers of Abū Hāshim al-Jubbā̄ì (d. 321/933) — and classical Ash'arīs developed radically different proofs. Both, however, started by positing the same central question: Why does an entity that comes

1 For a fuller exploration of the theological background, see my forthcoming article 'Metaphysical Causality, Contingency and Coming-to-be'. 
to be (hâadith) require another entity to originate it (muhdith)? In what follows, I shall only examine the standard Bahshami proof, as I argue that it became Avicenna's prime target of criticism. ${ }^{2}$

The Bahshamīs prove the existence of God by means of an analogy (qiyās) starting from the view that human acts $\left(f^{c} l\right)$ are entities-specifically accidents-which come to be either in the agent's body or in other bodies. An act-entity, they argue, depends on (ihtāja ilā) its agent ( fä́il). For instance, every time I act or refrain from acting, I do so in accordance with the presence or absence of prior motives and counter-motives corresponding to my act or abstention; this attests that my acts are necessarily dependent on my motives, and consequently on me as an agent. ${ }^{3}$ In the schema of the analogy, the actentity is said to be the primary case $(a s ̦ l)$, and its dependence on its agent is thus said to be a judgement $(h u k m)$ that applies to it. This judgement is then explained as being caused by a determinant ('illa), which is a specific attribute of the act-entity. The Bahshamis use several arguments to identify this determinant, which is argued to be the same for all act-entities, since they are all equally dependent on their agents. One example is the following disjunctionand-elimination argument: the attribute in question must either be the actentity's continuous existence (istimrār al-wujüd), or its prior nonexistence, or its coming-to-be. The first disjunct is eliminated on the grounds that acts often outlast their agents, and hence cannot depend on them continually. The construction of a building involves the production of accidents of composition between its constituent parts, and these accidents will continue to exist long after the death of their agent, the builder. The second disjunct is obviously false, as nonexistence, even when it precedes an entity's existence, is clearly nothing, and hence cannot be a cause for anything. It follows that the third disjunct must be true, and that an act-entity depends on its agent precisely with respect to the act-entity's coming-to-be. It is the entity's coming-to-be, rather than its continued existence, that is caused by the agent. ${ }^{4}$ Once the determinant has been established in the primary case, it can subsequently be used analogically to establish whether the same judgement applies to the secondary case $\left(\mathrm{far}^{\mathrm{r}}\right)$, which, in the problem at hand, is specifically the case of temporally originated entities that are not produced by humans. Since these entities come to be, they too must depend on an agent, who is argued to be a pre-eternal creator.

\footnotetext{
2 On the Ash'arī argument, see my forthcoming 'Metaphysical Causality, Contingency and Coming-to-be'.

3 Ibn Mattawayh, Majmü, 1, 69-72.

4 Mānkdīm, Sharh, 119; Ibn Mattawayh, Majmū', 1, 73.
} 
Another application of the principle, that an entity that comes to be depends on its agent only with respect to its coming-to-be, occurs in discussions of the continued existence of created entities. The flipside of the principle is that if an entity is of a type that has a capacity for continued existence (istimrār alwujūd), or persistence $(b a q \vec{a})$, its continued existence, once it comes to be, will be self-sustaining and uncaused. According to Bahshamīs, certain classes of created beings enjoy continued existence, in particular atoms and specific classes of accidents, such as accidents of colour, life and composition. Such beings depend on their agents, strictly speaking, only for their coming-to-be, but they then continue to exist autonomously, independent of an agent. A case in point is the accident of composition produced by a builder between the bricks of a building, which continues to exist even after the builder has died or become incapacitated. ${ }^{5}$ Certain other accident classes, such as the accidents of pain and sound, do not persist, so when such an accident comes to be, it will exist for a single moment and pass away. When such an accident appears to persist for an extended duration, the observer is given this impression only because a series of discrete instances of the same accident come to be uninterrupted at successive moments. ${ }^{6}$

In classical Ash'arism, all accidents without exception lack persistence and last no more than an instant. The colour of an object, hence, is recreated

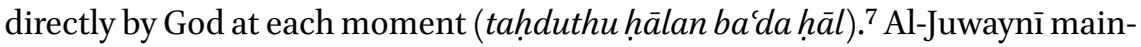
tained that atoms persist in existence so long as they contained instances of certain classes of accidents. ${ }^{8}$

The doctrine that an effect depends on its cause solely with respect to its coming-to-be is of far-reaching significance in earlier theology, as it underpins the macrostructure-so to speak-of the classical-kaläm worldview, with God as a pre-eternal voluntary agent, on the one hand, and the world as His temporally created act, on the other. According to this same principle, the philosophical notion that the world is pre-eternal, and hence did not come to be at some point in the past, immediately implies that, like God, it is uncaused (not to mention, of course, that it contradicts scriptural conceptions of creation, as theologians argued). Avicenna is keenly aware of the centrality of this theological doctrine, and for this reason gives considerable attention to refuting it and to advocating the antithetical doctrine that an effect depends on its agent only for its continued existence, and not for its coming-to-be.

5 Ibn Mattawayh, Tadhkira, 1, 68.

6 Ibn Mattawayh, Tadhkira, 1, 149-152; 1, 174.

7 Al-Anșārī, Ghunya, 2, 684.

8 Al-Juwaynī, Shāmil, 160. 


\subsection{Avicenna's Theory of Efficient Causation}

Turning now to Avicenna, we must start with his account of efficient causation. While Aristotle defines 'efficient cause' as 'the primary cause of change or rest', Avicenna distinguishes between two types of efficient causes ('illa fā'iliyya), or agents $(f \bar{a} \operatorname{c} l) .{ }^{9}$ He writes:

... Metaphysical philosophers do not mean by 'agent' only the principle of motion, as the naturalists mean, but the principle and giver of existence, as in the case of the Creator with respect to the world. As for the natural efficient cause, it does not bestow any existence other than motion in one of the forms of motion. Thus, in the natural sciences, that which bestows existence is a principle of motion. ${ }^{10}$

Metaphysical efficient causes, according to Avicenna, are causes that confer existence on things other than themselves, whereas natural (tabic $\bar{\imath}$ ) efficient causes (corresponding to Aristotle's efficient causes) only produce motion in existent things, which can be in the categories of quantity, quality, place or position. Avicenna accordingly describes metaphysical efficient causes as 'true' (haqīqī) efficient causes. ${ }^{11}$ God, the Necessary of Existence through Itself, confers existence on all beings and thus can be said to be their ultimate metaphysical efficient cause. The Giver of Forms is the metaphysical efficient cause of forms, which give actual existence to matter when they are combined with it.

In contrast to causes of existence, natural efficient causes are, in one respect, not true and essential (bi-l-dhät) efficient causes, but only have an accidental (bi-l-'arad) and auxiliary (mu'in) activity. ${ }^{12}$ As a principle of motion, a natural efficient cause prepares (mu'idd, muhayyi') matter to receive a new form, and it does so by effecting motion therein. Another, metaphysical efficient

$9 \quad$ Aristotle, Physics, II.3; Metaphysics, V 2. The following reading of Avicenna's theory of efficient causality is, in key respects, my own (see my forthcoming article 'Metaphysical Causality, Contingency and Coming-to-be'). On this subject, see also Richardson, 'Avicenna's Conception of the Efficient Cause'; Marmura, 'The Metaphysics of Efficient Causality in Avicenna'; Wisnovksy, 'Final and Efficient Causality in Avicenna's Cosmology and Theology'; McGinnis, Avicenna, 192-195.

10 Avicenna, Ilāhiyyāt, VI.1, 257 (Marmura's translation, 195, with slight adjustment).

11 Avicenna, Ilähiyyāt, VI.2, 265.

12 Avicenna, Ilāhiyyāt, VI.2, 265. On essential and accidental causes, see Tabīìyyāt, I.I.12, 74-75; Najāt, 521. On auxiliary causes, see Țabīìyyāt, I.I.10, 65. 
cause-namely, the Giver of Forms-completes (mutammim) the process by producing the new form in matter, when it has obtained a complete disposition (isti'dād tāmm) for that form. ${ }^{13}$ Avicenna explains that the father is not the real cause for the existence of the son, but only the cause for producing the motion that delivers semen to the mother's womb. The true cause that confers form on matter to produce the son is the Giver of Forms. Likewise, when a builder constructs a building, the motions of his body only produce motions in bricks and mortar, which is a motion in the category of place. The real cause of the combination $(i j t i m \bar{a})$ of these things, and consequently of the shape of the building and its existence as a building, is again the Giver of Forms, rather than the builder. ${ }^{14}$

According to Avicenna, a metaphysical efficient cause must be simultaneous with its effect (al-ilal al-haqiqqiyya mawjüda ma'a l-ma'ül). ${ }^{15}$ This means that the agent does not precede its effect temporally, and moreover that an effect that continues to exist after it has come to be does not become selfnecessitating, but must be sustained in existence constantly by an agent. ${ }^{16}$ This view is central to Avicenna's cosmology, and in the Najät it is substantiated in a lengthy argument that appears in the context of proving the existence of the Necessary of Existence through Itself. ${ }^{17}$ In brief, the argument is that since the possibility of a possible thing is linked to its essence, it is not only possible before it comes to be, but remains possible after it comes to be and throughout its continued existence. Avicenna writes:

Every thing that comes to be has a cause for its coming-to-be, and a cause for its continued existence (thabāt). The two may be one and the same thing, as in the case of a vessel that confers shape on a body of water. Or they may be two different things, such as the form of a statue, which is produced by an artisan and sustained (thabata) by the dryness of the substance of the element from which it is made. It is impossible for a thing that comes to be to become, after it has come to be, continually existing by itself such that it becomes, once it has come to be, necessary

\footnotetext{
13 Avicenna, Tabicityyät, I.I.10, 65. We return to Avicenna's conception of preparedness in the next chapter.

14 Avicenna, Ilāhiyyāt, VI.2, 264-265.

15 Avicenna, Ilāhiyyāt, VI.2, 265.

16 For the Neoplatonic background of Avicenna's theory of constant, eternal creation, see Sorabji, Matter, Space and Motion, 249 ff.; Kukkonen, 'Creation and Causation', $239 \mathrm{ff}$.

17 Avicenna, Najāt, $571-576$.
} 
of existence and such that it continues to exist independently of a cause for its existence and continued existence. ${ }^{18}$

So, if a possible thing comes to be, it does not become necessary through itself, but will be necessitated by an agent so long as that agent exists. Therefore, the continued existence of the effect depends on the continued existence of an agent that continues to necessitate it (and it may or may not be the original cause of its coming-to-be).

As to natural efficient causes, Avicenna writes in some places that these 'precede' (mutaqaddim) their effects; but this should not be taken at face value, for in the final analysis they too in fact must be simultaneous with their effects. A natural efficient cause is simultaneous with the motion it produces, which strictly speaking is its true effect. This motion, which of course takes place in time, may eventually engender preparedness in a substrate to receive a new form, which will then come to be and may subsequently continue to exist. The true agent of this new form will be a metaphysical efficient cause, rather than the cause of motion. So, a natural cause is simultaneous with its true effect, which is motion, but it precedes the effect to which it serves only as an accidental or auxiliary cause, which is the form. ${ }^{19}$

There may seem to be exceptions to the rule. For instance, if I throw a stone, my moving arm will be the agent for the forced motion (haraka qasriyya) produced in the stone while it is still in my hand; however, the stone will continue to move after I release it. So the motion of the stone continues after it becomes separated from the external force exerted by its agent. For Avicenna, however, there is more to the process than meets the eye:

Forced motion may [continue to] exist separately from the mover [i.e. when the mobile is separate from the mover], even though the mover's production of the motion has ceased. Now, it is impossible that the motion that is continuously being renewed should exist while its cause does not exist. So there must be some cause that preserves the motion, and that cause will exist in the mobile, producing an effect on it. ${ }^{20}$

Avicenna explains the continued motion of the stone after it separates from the hand by appealing to his theory of inclination (mayl), understood as an

\footnotetext{
18 Avicenna, Najät, 572.

19 Avicenna, Ilähiyyāt, VI.2, 264-265.

20 Avicenna, Țabīizyyät, I.II.8, 194-195 (partly based on McGinnis's translation).
} 
accidental power that occurs in the moving object and causes its motion. ${ }^{21} \mathrm{~A}$ stone, consisting predominantly of earth, has a natural inclination for downward motion, but if I throw it upwards, my arm will generate a foreign (gharib) forced inclination (mayl qasrī) in the object. This forced inclination will move it while it is in my hand. After I release the stone, the forced inclination continues to exist for a while in it and to cause its continued forced motion, until this foreign inclination is overcome by the stone's natural inclination or some other foreign force (for instance, if the object hits the ceiling) and is ultimately replaced with a different inclination. ${ }^{22}$ So, the continued motion of the stone will be caused continuously by its true and immediate agent, which is the inclination that inheres therein. 'It is impossible', Avicenna writes, 'that what arrives at a given end point [of motion] should do so without some [continually] existing cause that makes it arrive', i.e. a cause that exists throughout the motion. The cause in question is the inclination that supervenes upon the object. ${ }^{23}$ Inclination is thus the 'natural efficient cause' of the stone's motion ('natural', in opposition to 'metaphysical', rather than in opposition to 'forced'). Avicenna would say that the mover's arm, in turn, acts as another natural efficient cause, which produces preparedness in the matter of the stone to receive a foreign inclination, and that this inclination then comes to be through the agency of the Active Intellect, which acts as its metaphysical efficient cause and sustains it continuously in existence as long as there is preparedness in the matter of the moving object.

In the Metaphysics of the Shif $\bar{a}^{\prime}$, Avicenna argues against the three interconnected kaläm views that the agent precedes its effect, that it only causes the coming-to-be (hudüth) of the effect, and that the continued existence (baq $\left.\bar{a}^{\prime}\right)$ of the effect is hence uncaused and independent of the cause of its comingto-be. ${ }^{24} \mathrm{He}$ argues that the agent only causes the existence of the effect, and hence that the effect's coming-to-be, which denotes the fact that its existence was preceded by nonexistence, is strictly speaking uncaused. For, firstly, the prior nonexistence of the effect is not caused, except in the privative sense of being due to the absence of an efficient cause. Secondly, the fact that existence is temporally posterior to nonexistence too is not caused; for the existence of a temporally originated entity cannot possibly be except after nonexistence,

21 On Avicenna's theory of inclination, see Hasnawi, 'La Dynamique D' Ibn Sīnā'; McGinnis, Avicenna, 79-84.

22 Avicenna, Tabīìyyāt, I.IV.8, 46o-462.

23 Avicenna, Tabīìyyāt, I.IV.8, 460.

24 Avicenna, Ilāhiyyāt, VI.1-2, $259 \mathrm{ff}$. 
and what is not possible, but necessary, cannot be caused. The existence of the effect, by contrast, is possible and hence caused..$^{25}$

\subsection{Avicenna's Criticism of Kalām in the Ishärāt}

This brings us to Ishārāt II.5.1-3, which bears some correspondence to the discussion in the Shifä , just described. ${ }^{26}$ In these first three sections of Chapter 5 of the Physics and Metaphysics, titled 'On demiurgy and [atemporal] creation' ( $f i$ $l$-șun' wa-l-ibdāc), Avicenna frames his theory of metaphysical efficient causation against the backdrop of the foregoing theological, particularly Bahshamī, doctrines. In his full commentary on the Ishārāt, al-Rāzì insightfully groups the three Avicennan sections under one heading: 'On that the determinant for dependence on a cause is possibility, rather than coming-to-be, and that during its continued existence a thing is not independent of a cause' ( fíanna 'illat al-hāja ilā l-mu'aththir hiya l-imkān lā l-hudūth, wa-anna l-shay' hạal baqā̄i-hi lā yastaghni 'an al-sabab). ${ }^{27}$

In the first section (Ishārāt II.5.1), labelled a 'false notion' (wahm), Avicenna provides an account of the belief, held by 'ordinary people' ('ämma), that the effect depends (ta'alluq) on its agent precisely because the former was initially non-existent and then obtained its existence from the latter. ${ }^{28}$ That is to say, the two are connected purely on account of the effect's coming-to-be, although Avicenna does not mention the term 'haudüth' here. This conception of causation is intended in such expressions as 'to produce' (awjada), 'to make' (șana'a) and 'to act' (fáala) when used by ordinary people, that is, when they are employed in their ordinary, lexical senses. Such an understanding of agency is associated with 'awhām 'ämmiyya', i.e. it consists of an 'estimative proposition' (wahmiyya) stemming from the estimative faculty of the mind, which holds sway over the worldview of ordinary people. ${ }^{29}$ Avicenna observes that, according to this popular notion, once existence has been conferred on the effect, the effect will become independent of its agent, and will continue to

25 Avicenna, Ilāhiyyāt, VI.1, 260.

26 This overview of these three sections of the Ishārāt draws on my 'Al-Rāzī's Sharh'.

27 Al-Rāzì, Sharḥ, 2, 385.

28 Avicenna, Ishärāt, 3, 57-59.

29 On the Avicennan notion of estimative propositions (wahmiyyāt) and the faculty of estimation (wahm), see Avicenna, Najāt, 115-118; cf. Black, 'Estimation (wahm) in Avicenna'; Hall, 'The Wahm in Ibn Sina's Psychology'; Griffel, 'Al-Ghazālī's Use of “Original Human Disposition" (Fitra)', $10 \mathrm{ff}$. 
exist by virtue of the existence it obtained. He gives the example of the building, which continues to exist even after the builder is long dead. Some people-by whom he patently refers to the theologians-have the temerity even to assert that if it is conceivable for the Creator to pass away, the world would continue to exist, because the world is only dependent on God for its coming-to-be, to the exclusion of its continued existence. In their view, if the world depended on God for its existence per se, then every existent would likewise depend on another for its existence, and God Himself would have been dependent on another being for His existence.

In the second section (Ishärät II.5.2), Avicenna analyses (ḥallala) the expression 'agent' ( $f \bar{a}$ c $i l)$ and related expressions to their constituent elements, and he then separates those elements that are essential to agency from those that are accidental. ${ }^{30} \mathrm{He}$ argues that the expression should be defined essentially as a thing that engenders the existence of another thing after the latter was nonexistent. All other elements ordinarily included in the concept of 'agency' - such as the agent's being voluntary or natural, or its production of the effect directly or using an instrument - are accidental, and hence essentially extraneous to this concept. Otherwise, expressions such as 'voluntary agent', 'natural agent', 'acting through an instrument', and the like, would have involved either repetition or contradiction. Yet none of these expressions, Avicenna argues, are internally repetitive or contradictory.

In the same section, Avicenna goes on to raise the following question concerning his definition of agency. If the essential constituents of the concept of 'effect' are $(a)$ the existence of the effect, $(b)$ its prior nonexistence, and $(c)$ the temporal posteriority of its existence to its nonexistence, then on account of which of these constituents does the effect depend on its agent? Through a process of elimination, Avicenna argues that the constituent in question must be $(a)$ the existence of the effect. For $(b)$ nonexistence, obviously, is uncaused, and hence cannot be the constituent on which the dependence of the effect on its agent hinges. As to $(c)$ the temporal posteriority of the existence of a temporally originated thing to its nonexistence, this is a necessary attribute of the effect, and as such uncaused. The section closes with a further question: If the effect depends on its agent on account of its existence, then is the existence of a temporally originated thing caused because $(a .1)$ it is not necessary (i.e. possible), or (a.2) because it was nonexistent before it obtained its existence (i.e. it is temporally originated)?

3o Avicenna, Ishārāt, 3, 59-65. On Avicenna's notion of 'analysis', see McGinnis, 'Penetrating Question', 64-67. 
This question is answered in the third section (Ishärāt, II.5.3), labelled 'concluding discussion and a pointer' (takmila wa-ishära) $\cdot{ }^{31}$ Avicenna here argues that the conception 'necessary of existence, not in itself, but through another' is a general conception that is true both of entities that have always (däiman) been necessitated through another and of those that have been necessitated through other entities for a finite duration of time. The conception 'preceded by nonexistence', on the other hand, is more specific, as it is true of the latter class of entities, but not of the former. Both conceptions are predicable of 'being dependent on another for existence'. However, if two conceptions-one general, and one specific - are predicated of the same conception, then the more general conception will be predicated of this notion essentially and in the first place, and the more specific conception will be predicated of it non-essentially and secondarily. Therefore, an effect depends on its agent because its existence is necessitated through another, and not because its existence is preceded by nonexistence. 'Being necessitated through another', i.e. being possible of existence, is an attribute that characterises effects permanently, and not only at the moment they come to be; so it follows that the dependence of effects on their causes must be equally permanent.

\subsection{Al-Ghazālī's Criticism}

The Avicennan conception of agency just described is attacked in Discussion 3 of al-Ghazālì's Tahäfut, titled, 'On showing [the philosophers'] obfuscation in asserting that God is the agent ( $f \bar{a} c i l)$ and maker of the world, that the world is created and produced $\left(f^{i} l\right)$ by Him, and that with them these [expressions] are used figuratively rather than literally'. ${ }^{32} \mathrm{Al}-\mathrm{Ghaza} l \overline{1}$ introduces the discussion by identifying three respects in which the philosophers misuse the expressions $f^{i} l$ and $f \bar{a}^{\prime} i l$ by employing them in the context of cosmogony: (1) an 'agent' must be possessed of volition and knowledge, whereas God, in their view, is an involuntary cause; (2) an 'act' must come to be in time, whereas the world, according to the philosophers, is pre-eternal; and (3) they maintain that God is absolutely simple, and that from an absolutely simple entity only one, simple effect proceeds, so they are in no position to assert that the world, which is composed of different things, proceeds from God. ${ }^{33}$ Here, we are only concerned with the second criticism.

\footnotetext{
31 Avicenna, Ishārāt, 3, 65-71.

32 Al-Ghazālī, Tahāfut, 95-132, esp. 103-109.

33 Al-Ghazālī, Tahāfut, 95-96.
} 
Against Avicenna's theory of agency and his conception of atemporal coming-to-be, al-Ghazālī reasserts the classical kalām definition of 'act' as bringing a thing from nonexistence into existence in time ( $m a^{\prime} n a \bar{l} l-f_{i}^{\prime} l i k h r a ̈ j a l-s h a y y^{\prime}$ min al-'adam ilā l-wujūd bi-ihdāthi-hi). ${ }^{34} \mathrm{He}$ then paraphrases Avicenna's defence of his position, including his previously mentioned disjunction and elimination argument, in which he establishes that the effect depends on its agent $(a)$ with respect to its existence, by eliminating that it depends on it on account of either (b) its prior nonexistence or $(c)$ the temporal posteriority of its existence to its nonexistence. By eliminating ' $b$ ' and ' $c$ ', Avicenna eliminates that this dependence rests on the effect's (temporal) coming-to-be. ${ }^{35} \mathrm{Al}$-Ghazâlī proceeds to respond to this argument as follows:

The act depends on (yata'allaqu bi-) the agent with respect to its comingto-be, not with respect to its prior nonexistence, nor with respect to its being existent simpliciter. For, according to us, [the act] does not depend on [the agent] at the moment following its coming-to-be, during which it exists, but rather depends on it at the moment of its coming-to-be and inasmuch as this [occurrence] is coming-to-be and coming from nonexistence into existence (khurüj min al-'adam ilā l-wujūd). If the notion of coming-to-be is denied as true of [the supposed act], it cannot be conceived of as an act, or as being dependent on an agent. ${ }^{36}$

So, al-Ghazāī concedes Avicenna's elimination of disjunct ' $b$ ', that the effect's dependence on its agent hinges on the effect's prior nonexistence. He also rejects disjunct ' $a$ ', which Avicenna affirms. What al-Ghazālī then does is effectively to propose a fourth disjunct: $(d)$ that the effect depends on its cause only for its coming-to-be, understood as an occurrence that takes place in an instant, which is the moment at which something that was nonexistent becomes existent. This is precisely the theologians' understanding of coming-to-be and its correlation with agency, which is why al-Ghazālī introduces it by 'according to us' ('inda-nā). Accordingly, he explains, it is inconceivable for a thing that does not come to be in time to be produced and to have an agent. What he does here is simply to assert his and the theologians' position, without supporting it with an argument that would force an Avicennist into a corner. But this tactic seems justified, as the onus is arguably on Avicenna to eliminate disjunct ' $d$ '.

34 Al-Ghazāīì, Tahāaut, 103.
35 Al-Ghazāì, Tahāfut, 103-106.
36 Al-Ghazālì, Tahāfut, 106. 
Al-Ghazālī then turns to disjunct ' $c$ ' - that the effect owes its dependence on its agent to the temporal posteriority of its existence to nonexistence-which Avicenna eliminates on the grounds that the temporal posteriority of existence to nonexistence is a necessary attribute of the existence of a temporally originated thing, and as such cannot be dependent on the agent's activity. It is true, al-Ghazāli responds, that temporal posteriority to nonexistence is not a caused attribute of existence, but it is nonetheless a condition (shart) for existence to be caused by an agent. Being a condition for the agent's act, it need not be produced by the agent, just as the agent's own existence, capacity, volition and knowledge are conditions for his acts, but are not produced by him. ${ }^{37}$

So, al-Ghazālī rejects Avicenna's analysis of coming-to-be into a prior state of (continued) nonexistence, a subsequent state of (continued) existence, and an attribute of (continued) existence. Instead, he reasserts the classical kaläm conception of coming-to-be as, strictly speaking, an occurrence that lasts no longer than an instant.

The remainder of the section is of less relevance to our present purposes, as it turns to the question of how God can be a pre-eternal agent, but produce acts in time. One pertinent point that transpires, however, is that al-Ghazâlī, in this discussion, seems to advocate an Ash'arī form of occasionalism. He writes that constant motion should be understood in terms of a series of successive instants, or 'parts' ( $a z j \bar{a}$ ), of motion, each of which comes to be ex nihilo, out of nothing (hâdith 'an 'adam). ${ }^{38}$ It is precisely this classical Ash'arī view that al-Ghazāli champions in his theological manual, the Iqtișād, where he maintains that accidents lack continued existence and last for no more than an instant, and that the accident hence passes away (in idām) at each instant, although it can be renewed (tajaddud) at the next instant. This, he writes, is true of all classes of accidents, even colours. Following al-Juwaynī, he maintains that atoms, by contrast, enjoy continued existence so long as they contain instances of certain indispensible classes of accidents. ${ }^{39}$

In sum, while al-Ghazāli declares his opposition to the Avicennan thesis that an effect depends on its agent with respect to its existence, as opposed to its coming-to-be, he only asserts its direct antithesis - namely, the classical kaläm view that a temporally originated thing depends on its agent for its coming-to-be, and that it continues to exist thereafter independently of the agent-but he does not substantiate it. This is hardly surprising, as al-Ghazāli’s

37 Al-Ghazālī, Tahāfut, 106-107.

38 Al-Ghazālī, Tahāfut, 109 .

39 Al-Ghazālī, Iqtișād, 37. 
express task in the Tahäfut is to attack Avicenna's teachings, and not to lay out and to defend an alternative system. In Discussion 3, his focus is on Avicenna's theory of efficient causality, not in abstraction from its theological context, but only insofar as it underpins his theory of the pre-eternity of the world.

\subsection{Al-Mas'ūìi’s Commentary}

Al-Mas'ūdī nowhere mentions al-Ghazālī in relation to this specific problem, yet I will argue towards the end of the present section that the Tahäfut is a key part of the background. For now, we must circle back to the Ishärät.

Although Ishärāt II.5.1-3 is the discussion in which Avicenna refutes the classical kaläm conception of agency and advances his own theory, al-Mas'ūdī opens Section 9 of the Shukūk by citing a shorter passage, Ishärāt II.4.10. He turns to Ishärät II.5.1-3 in the last quarter or so of the section. The structure of Section 9 is as follows:

1. Al-Mas'ūdī cites Ishārāt II.4.10, where Avicenna argues that the existence of every possible being is conferred on it by another being. ${ }^{40}$

2. Al-Mas'ūdī interprets the passage briefly, and submits an alternative theory, according to which the continued existence of some possible beings does not require a continuous cause of existence. ${ }^{41}$

3. Four particular cases are then adduced as evidence for al-Mas' ūdì's thesis. ${ }^{42}$

4. A possible counter-argument to this thesis is addressed. ${ }^{43}$

5. A second possible counter-argument to the thesis is addressed. ${ }^{44}$

6. Al-Mas'ū ūi then cites Ishārāt II.5.1-3, in which, as we have seen, Avicenna argues against the view that an effect depends on its cause only with respect to its coming-to-be, as opposed to its continued existence. ${ }^{45}$

7. This Avicennan argument is confuted. ${ }^{46}$

So, al-Mas' ūdī's first order of business in this section, particularly in parts $2-5$ of the above outline, is to counter an Avicennan theory with his own alternative

$\begin{array}{ll}40 & \text { Shukūk,262.3-6. } \\ 41 & \text { Shukūk,262.7-263.2. } \\ 42 & \text { Shukūk,263.3-265.3. } \\ 43 & \text { Shukūk, 265.4-266.7. } \\ 44 & \text { Shukūk,266.8-267.7. } \\ 45 & \text { Shukūk,267.8-268.11. } \\ 46 & \text { Shukūk,268.12-269.11. }\end{array}$


theory, before attending to Avicenna's arguments. It is only in part 6 that he cites and addresses the most relevant argument deployed by Avicenna in support of his thesis, a thesis that in effect is merely asserted in the passage cited in part 1. We have already noted in Chapter 2 above how, commenting on another section of the $S h u k \bar{u} k$, al-Rāzī finds this procedure objectionable. ${ }^{47}$

Al-Mas'ūdī's choice to centre his discussion on Ishārāt II.4.10, which occurs in the course of Avicenna's proof of the existence of the Necessary of Existence through Itself, may be influenced by a reading of the Najāt, where, as mentioned already, this is precisely the context in which Avicenna establishes the view that a continuously existing effect must be sustained continuously in existence by a coeval agent. So although it occurs earlier in the book, the passage arguably presupposes Ishārät II.5.1-3, in which this point is substantiated. Ishārāt II.4.10 goes as follows:

Pointer. That which, on account of itself, is characterised only of possibility cannot become existent through itself. For its existence does not preponderate over its nonexistence on account of its being possible. So if either [existence or nonexistence] becomes preponderant, that must be due to the presence or absence of something. Therefore, the existence of every possible being must be due to something other than itself. ${ }^{48}$

Al-Mas'ūdì's commentary begins by considering two possible readings of this passage: either $(a)$ that the existence of a possible thing depends on another only at the moment it is initiated (ibtida $\vec{a}^{3}$ ), or $(b)$ that a possible thing depends on another for, and throughout, its continued existence (dawām al-wujūd wa$b a q \bar{a} u-h u)$. He has no complaints against the former view. Reading ' $b$ ', however, is the correct reading, as confirmed by Ishārät II.5.1-3 cited later in the section; and it is thus the view that the ensuing discussion attacks. ${ }^{49}$

So, the section targets Avicenna's general claim that all things possible of existence are dependent for their continued existence on a continuous and simultaneous efficient cause, and defends the counter-thesis that, in principle, a thing possible of existence requires a cause only to bring it into being, but then continues to exist independently of an efficient cause. The preponderator,

47 See pp. $5^{8-59}$ above.

48 Avicenna, Ishärāt, 3, 20.

49 On that the notion that a metaphysical efficient cause is simultaneous with its effect is central to Avicenna's proof of the existence of the Necessary of Existence through Itself, the context in which Ishārāt II.4.10 occurs, see Section 5.1 below. 
in other words, is only needed to tip the balance, but not after the balance has been tipped. Al-Mas'ūdī initiates his response by arguing that things that come to be fall under two classes according to whether or not they possess self-sustaining existence, and consequently whether or not they depend on their agent to sustain them in existence. The first is the class of things that possess continued existence, and hence need to be brought into being by an agent but afterwards continue to exist without having to be perpetually caused. This class includes all substances and most types of accidents. The second is the class of accidents that lack self-sustaining continued existence, and these are of two types.

The first sub-class includes accidents that appear to persist, but are actually 'renewed' (tajaddada) constantly by a cause. The only example we are given of this type of accidents is motion in space. The notion of 'renewal' here may seem to presuppose the atomistic conception of time espoused in classical kalām, but is in fact borrowed from Avicenna (who, in turn, adapts it from the Mu'tazila). ${ }^{50}$ Locomotion, according to Avicenna, is produced in the mobile constantly by the inclination that supervenes upon it. This renewal of motion is not atomistic, but continuous: locomotion is 'continuously renewed' (yatajaddadu 'alā l-ittișāl), as Avicenna writes. ${ }^{51} \mathrm{On}$ such accidents, al-Mas'ūdī writes:

Among accidents are some that have no fixed disposition or real continued existence (hay'a qārra wa-baqā' haqīqū), but of which similar instances are renewed in succession (tatajaddadu amthälu-hu 'alä l-ta'a $\bar{a}-$ $q u b)$. These are called 'continually existing' only in a figurative sense (yusammā bāqiyan majāzan). For this continued existence is dependent on a sustaining cause ('illa mubqiya). ${ }^{52}$

Al-Mas'ūdī accepts the Avicennan conception that locomotion must be constantly renewed by the agency of inclination. But he goes on to deny the supposition (zann) of 'some mutakallimūn' that all accidents likewise lack continued existence, a reference, it seems, to Ash'arīs and Māturīdīs.

The second sub-class includes accidents that, of themselves, lack continued existence, but may be sustained in existence by a force (qasr) applied con-

50 See Rashed, 'Natural Philosophy', 295-302, esp. 299-300. On Avicenna's theory of motion and inclination, see also McGinnis, Avicenna, 59-84; idem., 'A Medieval Arabic Analysis of Motion at an Instant'; Hasnaoui, 'La Dynamique d' Ibn Sīnā'.

$5^{1}$ Avicenna, Țabīiyyāt, I.II.8, 194 (see p. 91 above).

52 Shukūk, 262. 
stantly by an external agent. Such accidents supervene on a thing whose nature is contrary to theirs by a cause that forces (qasara) them thereon.

Only in these two cases, according to al-Mas'ū ūì, does an accident lack inherent persistence and depend on a constant efficient cause to sustain it constantly in existence, so long as it exists. They are hence the only exceptions to the general principle that he is in the process of defending-namely, that entities depend on their agents for their coming-to-be, but not for their continued existence. 'All substances and accidents other than these continue to exist independently of the continued existence of their cause. ${ }^{53}$

Not all forced effects, however, break this general principle. For often, as al-Mas'ūdī argues, their continued existence does not require a simultaneous sustaining efficient cause, and these exceptions provide support to his central thesis that most effects persist independently of an agent (so they are exceptions to the exceptions to this principle). He writes:

If a forced existent (mawjūd qasrī) becomes fixed and set firmly in the substrate, and if the cause, which produces it and suppresses the nature that is contrary to it, intensifies, it may persist for some duration after the passing away of its cause, until the [thing's] innate nature strengthens to the extent that it repels it and causes it to pass away. ${ }^{54}$

Al-Mas'ūdī gives two examples. First, when a body of water is affected by intense fire, heat will be forced onto it to the extent that it overcomes the natural coolness of water, which is its contrary. This heat will persist in the water for an extended duration after it has been removed from the fire, since the nature of water can only overcome heat and restore coolness gradually. Were it not for the natural activity of water, heat would remain perpetually in a heated body of water. The fact that it persists for a while after the influence of the fire comes to an end confirms that its continued existence is independent of its efficient cause; for otherwise a heated body of water would turn cool as soon as it has been removed from the fire. ${ }^{55}$

The same sequence of events can be observed when a stone is thrown upwards. Being predominantly made up of the element earth, a stone has a natural inclination $($ mayl) for downward motion, but will travel in upward motion, contrary to its natural inclination, by a forced inclination produced by the

\footnotetext{
53 Shukūk, 263.

54 Shukūk, 263.

55 Shukūk, 263.
} 
thrower. Al-Mas'ūdi reasons that the persistence of upward motion in the stone after the thrower has released it confirms that the motion is caused by a forced inclination that continues to exist in the stone throughout the duration of its upward motion. The correlation between the distance traversed by the stone in its upward motion and the force exerted by the thrower indicates that the cause of this forced inclination is the initial propulsion $\left(d a f^{c}\right)$ generated by the thrower's motion. 'Had the continued existence of the effect been dependent on the continued existence of its cause, it would have been impossible for the [forced] inclination to continue to exist after the passing away of propulsion., ${ }^{56}$

Al-Mas'üdī gives two further examples of effects that persist in the absence of their agents. First, colours, which are accidents of quality, continue to exist in bodies. When an object is dyed by the application of henna, the resulting colour will persist for a long time afterwards. The dyeing process does not occur by the adhesion of henna particles to the object's surface - this is attested by the facts that the green colour of henna differs from the brown or red colour produced in the dyed object, and that the dye cannot be removed with vigorous washing and scrubbing. Therefore, henna acts as the efficient cause of the colour produced in the dyed object, and this effect continues to exist after its cause has become absent. ${ }^{57}$ Second, a body may undergo elemental change by the agency of an efficient cause, and the new elemental form it acquires may continue to exist after the passing away of its cause. For instance, when air is cooled it turns into water, and when water is heated it turns into air; both bodies may remain in the resultant form even when they are no longer affected, respectively, by coolness and heat. ${ }^{58}$

This last case, al-Mas'ūdī points out, may elicit the following counterexplanation, which may be given in support of the Avicennan thesis. Even though the new elemental form comes to be by one cause, it will thereafter be sustained in existence by a different cause, namely the dependence of matter, with respect to its existence, on form. Matter cannot be devoid of form, but must constantly be in receipt of some form or other. It is equally receptive of all forms, and is not inherently predisposed to some forms over others. So when a given form comes to be in a material substrate, it will come to be by an efficient cause; and if the activity of that cause then comes to an end, the form it has produced will continue to exist in its material substrate. Matter itself will preserve (hafiza, abqā) that form, and as such be the preserving

\footnotetext{
$5^{6} \quad$ Shukūk, 264.

57 Shukūk, 264.

$5^{8}$ Shukūk, 264-265.
} 
cause ('illa mubqiya) that sustains its continued existence. Matter would preserve form in the absence of its originating cause by holding on to it, so to speak, since it is impossible for matter ever to be devoid of form. It follows that although the cause of coming-to-be may become absent, the effect will nonetheless be sustained in continued existence by a different, simultaneous cause. ${ }^{99}$ This counter-explanation is introduced by, 'If it is said', which provides no clues as to whether al-Mas'ūdī reproduced it from an earlier source, or whether he postulated it himself on behalf of Avicenna and his followers. The latter is most likely the case; for the notion that matter acts as a preserving cause for form is not one that Avicenna would advocate, but is in fact a view that he explicitly rejects. According to Avicenna, although matter, when combined with form, serves as one of the two proximate causes of body-namely, the material cause - it certainly does not cause the form with which it is combined. For matter is associated with passive potentiality and is actualised by the form it receives, but cannot itself be an actualising cause. It is moreover ontologically posterior to form; so to be a cause for form, it would become essentially prior to it. ${ }^{60}$ The existence of form in suitably prepared matter, for Avicenna, is produced directly by the Active Intellect, which acts as its (metaphysical) efficient cause; and form is sustained in existence by its continued agency.

Responding to this possible counter-explanation, al-Mas'ūdī argues that 'if you allow this with respect to [substantial] forms, then you must do the same with respect to all accidents, and indeed with respect to all possible existents. ${ }^{\prime 1}$ Take, for instance, the existence and nonexistence of the accident of the colour black. No material substrate can be devoid of either of these two contraries, just as it cannot be devoid of substantial form; yet matter is not inherently predisposed to either the presence or absence of blackness. If either possibility becomes actual in a given subject, it will do so by the influence of a preponderator (murajiih); and if afterwards the alternative possibility replaces it, it will only do so, again, by the influence of some other preponderator. Yet in the absence of this second preponderator, the state of affairs brought about by the first preponderator will persist, not by an external cause, but purely by virtue of the fact that the underlying subject cannot be devoid of either possibility. Al-Mas'ūdī writes:

\footnotetext{
59 Shukūk, 265.

6o Avicenna, Ilāhiyyāt, II.4, 83-85; VI.1, 258.

61 Shukūk, 265.
} 
If the actual state of affairs is nonexistence, it will persist (istamarra) until the cause of existence comes to be; and if the actual state of affairs is existence, it will persist until the cause of nonexistence comes to be. The initial occurrence of either of the two contraries requires a cause. Thereafter that cause may become absent, yet the actual alternative will persist by virtue of a different cause, which is the impossibility that the subject be devoid of either of the two contraries. ${ }^{62}$

The radical divergence of this position from Avicenna's account of causation and possible existence is striking. Al-Mas'ūdì's analysis of the coming-to-be and continued existence of possible things has some explanatory power, but it hardly has any argumentative power against Avicenna's account. Most obviously, al-Mas'ūdì does not seem to subscribe to the distinction between metaphysical efficient causes, which produce existence, and natural efficient causes, which produce motion. What is more, unlike Avicenna, as already noted, he maintains that a material substrate can act as a preserving cause for a species form engendered by some initial cause.

Al-Mas'üdì then considers evidence that may be adduced in support of the Avicennan thesis that the continuous existence of the effect depends on the continuous existence of its cause: namely, that light is caused by fire or the sun, and ceases to be as soon as its cause becomes absent. ${ }^{63} \mathrm{He}$ responds that such evidence is insufficient for establishing the general proposition it is meant to support. It is enough to produce just a single case in which the effect outlasts its efficient cause, for the Avicennan thesis to collapse. What is more, the explanation of the concomitance (taläzum) between cause and effect in cases in which the two are inextricably concomitant with respect to their continued existence and nonexistence, such as light and its cause, may be more specific than the general principle that the continued existence of all effects depends on the continued existence of their causes. This more specific explanation, al-Mas'ūdī opines, may be unknown to us: it could be, for example, that light, like motion, needs to be renewed constantly by its cause, or that light is a forced effect that is contrary to the nature of air, and is repelled swiftly by it, so it passes away without a trace as soon as the cause that forces it on air becomes absent.

Finally, al-Mas'ūdī turns to Ishārät II.5.1-3 to address Avicenna's abovedescribed elimination argument, which he describes as an investigation and

62 Shukūk, 266.

63 Shukūk, 266-267. 
disjunction argument (al-sabrwa-l-taqsim). ${ }^{64} \mathrm{He}$ confutes the argument on the grounds that the disjunction set out by Avicenna is not exhaustive, since it does not account for all conceivable divisions. ${ }^{65}$ As mentioned, Avicenna considers three options for the grounds on which a thing that comes to be depends on its agent: $(a)$ the existence of the effect, $(b)$ its prior nonexistence, and $(c)$ the temporal posteriority of its existence to its nonexistence. Al-Mas'ūdī accepts the sub-arguments that Avicenna puts forth to eliminate the last two disjuncts. However, he does not automatically concede disjunct ' $a$ ', since, he avers, there is in fact a fourth disjunct that Avicenna neglects to consider: namely, $(d)$ that a thing that comes to be depends on an efficient cause because of the effect's 'coming from nonexistence into existence' (al-khurüj min al-'adam ilä l-wujüd, or al-dukhül fi l-wujüd). This, we are told, is precisely the sense denoted by 'coming-to-be' (hudūth, hușūl), as well as by 'change' (taghayyur, tabaddul), 'motion', 'alteration' (istihāala), and 'affection' (infical, ta'aththur). The process of coming-to-be (husșull) is different from each of $(a)$ that which obtains (ḥassill) from the process, namely existence, $(b)$ prior nonexistence (which is obvious), and (c) the attribute (sifa) of the existence that obtains from the process, which is the attribute of being preceded by nonexistence. 'Coming-to-be', al-Mas'ūdī asserts, belongs to the category of affection (an yanfa'ila), and as such is not the same as 'that which comes to be' (hädith) - that is, the effect (athar), or more precisely the existence of the effect-which belongs to the category of quality. The thing's 'becoming existent' (șayrüratu-hu mawjūdan) is different from existence itself, and irreducible to a mere attribute of existence. This distinction between the process, or event, of coming-to-be and its subsequent, enduring outcome is analogous to the distinction between 'being heated' (tasakhkhun) and heat itself (sukhüna), and between 'becoming black' and the colour black itself. Al-Mas'ūdī submits that this occurrence, which Avicenna fails to consider in his disjunction, is in fact the true grounds for the effect's dependence on its agent. The agent, in other words, is responsible for the affection (that is, the process of bringing something into being), rather than for the effect itself (that is, existence), which hence persists independently of the agent.

Leaving aside al-Mas'ūdī's appeal to the Aristotelian categories here, we can identify two likely sources for his analysis of coming-to-be. The first is Discussion 3 of al-Ghazālī's Tahāfut, examined earlier. Al-Ghazālī, as we have

\footnotetext{
64 Shukūk, 268. See pp. 94-95 above.

65 On exhaustive and non-exhaustive disjunctions, see: Shihadeh, 'Argument from Ignorance', $192 \mathrm{ff}$.
} 
seen, eliminates disjuncts ' $a$ ' and ' $b$ ' of the disjunction set up by Avicenna. Yet instead of affirming the remaining disjunct ' $c$ ' (the temporal posteriority of the effect's existence to its nonexistence), he invokes the earlier-kaläm definition of 'hudüth', namely the effect's 'coming from nonexistence into existence' (al-khurüj min al-'adam ila l-wujüd), which is an occurrence as opposed to an attribute of the subsequent existent. ${ }^{66}$ It is precisely with respect to this occurrence, al-Ghazâlī asserts, that the effect depends on its agent. Yet he neither elaborates nor emphasises the distinction between the two senses of 'hudüth'. Al-Mas'ūdī seems to pick up on the distinction subtly made by al-Ghazālī, and on its basis he introduces the fourth division, ' $d$ ', into Avicenna's disjunction, differentiating it from division ' $c$ '.

The distinction that al-Mas' ūdī proposes between divisions ' $d$ ' (the effect's coming-to-be) and ' $a$ ' (the effect's existence) recalls the distinction that Māturīdīs make between 'creating' (takwīn) and the 'thing created' (mukawwan). One of the central tenets of Māturīdism, and a major point of conflict with Ash'arism, is that 'Creator' (khäliq) is affirmed as a real and pre-eternal attribute of God over and above His power (qudra). The activity of this attribute- that is, creating $(k h a l q$, takwin), or bringing into being $(\bar{y} j \bar{d} d)$ - belongs to the attribute itself, and as such is ontologically distinct from the things that exist separately from God and are the products of this activity. ${ }^{67}$ For should 'creating' boil down to the mere existence of created things, it would not be a real attribute of God, but only a relational one, nor would it be pre-eternal, as it would apply to God only while He is actually creating things. Ash'arīs, by contrast, maintain that God creates things, which strictly speaking are His acts, directly through His capacity, without the involvement of a distinct attribute or intermediary process of 'bringing into being'. In their view, 'creating' (khalq) and 'what is created' (makhlüq) are identical; and so are 'coming-to-be' (hudüth) and 'what comes to be' (muhdath). ${ }^{68}$ Though the Māturīdī theory of the divine attribute

66 Al-Ghazālī, Tahāfut, 106 (see pp. 96-97 above).

67 See, for instance, al-Māturīdī, Tawhìd, 110-113; al-Nasafì, Tamhīd, 191ff.; al-Ṣābūnī, Kifāya, 135-147; Gimaret, Théories de l'acte humain, 188 ff.; Rudolph, al-Mãturīdì and the Development of Sunnī Theology, $278 \mathrm{ff}$.

68 Al-Anșārī, Ghunya, 1, 438ff. Classical Ash'arīs rarely pay attention to the Māturīdī position, or to other Māturīdī doctrines for this matter. Al-Anșānī ascribes the distinction between 'creation' and 'created' to the Karrāmiyya and Abū l-Hudhayl al-'Allāf (d. between 226/840 and 236/850) and Abū Hāshim al-Jubbā'ī of the Mu'tazila (Ghunya, 1, 340-341; 1, 439). To my knowledge, one of the earliest Ash'arīs to respond to this Māturīdī doctrine is al-Rāzī (Muḥașșal, 435-437; Máălim, 59-6o). 
of 'creating' is in itself of little direct relevance to al-Mas'ūdì's response to Avicenna's theory of efficient causation, the distinction between the process of creating and that which is created is most probably what inspires this response. This distinction would have been familiar to scholars based in Bukhara, and indeed it was the subject of one of the debates in which Nūr al-Dīn al-Ṣābūnī (d. 580/1184), the chief Māturīdī in town, chose to engage al-Rāzī during his stay in the city. ${ }^{69}$

So, what — we may ask — motivates al-Mas'ū dì's criticism of Avicenna's views on efficient causation and the continued existence of things possible of existence, and his own counter-thesis? It will be recalled that, in the Ishärät and the Naja $t$, this problem is treated in the context of theology, particularly both in the course of proving the existence of the First Cause and in the discussion of cosmogony, where it plays a key role in Avicenna's theory of the pre-eternity of the world. We have also seen how in a discussion on creation in the Tahafut, al-Ghazāli approaches the problem as having a purely theological import. So, although Section 9 of al-Mas'ūdì's Shukūk makes no mention of God, but treats the problem as though it only revolved around an abstract metaphysical principle, we can safely assume that to him it has more or less the same theological relevance it has to Avicenna and al-Ghazālī. There is a clear hint at this theological background in the conclusion of the section:

What is dependent on the act and the agent is the affection; for it is inconceivable without [the agent's acting]. As to the [thing that becomes] realised and actual, it has no dependence on the agent; for the act is the bringing-into-being, and must be preceded by nonexistence. It thus becomes evident that the initiation of existence depends on an efficient cause only for the coming-to-be [of the effect]. However, it is inconceivable that coming-to-be endures perpetually; for it must be preceded by nonexistence. ${ }^{70}$

This closing statement is the closest that al-Mas' ūdī comes to asserting his ultimate goal in the question under discussion. Once it is established that the coming-to-be of a thing is caused, and that its continued existence is uncaused, it will immediately follow that a pre-eternal thing cannot be caused, and consequently that for the world to be dependent, one way or another, for its existence

\footnotetext{
69 Al-Rāzī, Munāzarāt, 17-20. The same problem was also the centre of a debate in which al-Rāzī engaged in Ghazna (Munāzarāt, 21-22).

70 Shukūk, 269 .
} 
on God it must be temporally originated. The key expression in the passage is 'the precedence of nonexistence' (taqaddum al-'adam): for things to be created, they must be preceded by nonexistence (that is, in the temporal sense of precedence). Al-Mas'ū dì's assertion that coming-to-be cannot persist perpetually, beyond the moment of coming-to-be, seems targeted against Avicenna's notion of atemporal 'essential coming-to-be' (hudūth dhātī), to which he appeals in explaining the causedness and atemporal createdness of pre-eternal possible beings. ${ }^{71}$ To the extent that he re-establishes the connection between causation and coming-to-be, al-Mas ūdì reasserts the classical kalām thesis, also endorsed by al-Ghazālī, that the effect depends on its agent for its coming-to-be, but not for its continued existence.

That said, al-Mas'ūdī clearly does not espouse the occasionalist doctrine of continuous creation advocated in classical Ash'arism and Māturīdism, as he does not maintain that all accidents lack continued existence of themselves and need to be renewed by God at each moment. This is where he departs with al-Ghazālì's more conservative treatment of the problem. His position appears, to an extent, analogous to the previously described Bahshamì Mu'tazilì position, in so far as it affirms that the continued existence of certain classes of simple created entities is uncaused. Yet it clashes with Bahshamì ontology at important points, not least the fundamental questions of what an accident is, and which types of accidents have, and which ones lack, continued existence, and under which circumstances. What is more, al-Mas'ū ūi, in contrast to Bahshamīs, affirms natural causality: so, for instance, it is the nature (ta $\left.a b^{c}\right)$ of water, rather than the power of God, that engenders coolness.

So if al-Mas'ūdī's discussion is driven, at least in part, by theological motives and commitments, it seems that he salvages the doctrine of the creation of the world ex nihilo at the expense of denying constant creation. God brings things into being, but His creatures then continue to exist and to operate autonomously in accordance with their inherent natures. 